\title{
Analisis Penggunaan Media Papan Planel untuk Meningkatkan Minat Belajar Pada Materi Rantai Makanan di Sekolah Dasar
}

\author{
Zulhulaifah M.H,1 Selvi Wulandari ${ }^{2}$ \\ Universitas Khairun Ternate \\ Jl. Bandara Baabullah Kampus 1 Unkhair, Kelurahan Akehuda Kota Ternate Kode Pos 97728 \\ Email: zulhulaifahm4@gmail.com, selviwulandari2021@gmail.com
}

\begin{abstract}
Abstrak: Penelitian ini dilakukan dengan tujuan untuk mengetahui pengaruh penggunaan media papan planel untuk meningkatkan minat belajar pada materi rantai makanan di Sekolah Dasar. Dengan jenis penelitian yang digunakan adalah studi pustaka (library research). Teknik pengumpulan data dalam penelitian ini yaitu dengan mengumpulkan jurnal-jurnal ilmiah yang dianggap relevan dengan variabel penelitian yaitu media papan planel, minat belajar dan materi rantai makanan. Kemudian disajikan dan dianalisis serta diolah supaya ringkas dan sistematis. Dalam penelitian studi pustaka (library research), terdapat dua sumber data yaitu sumber data primer dan sumber data sekunder. Teknik analisis data yang digunakan yaitu peneliti menggunakan tiga cara analisis data kualitatif yaitu reduksi data, penyajian data, dan penarikan kesimpulan data/verifikasi. Hasil penelitian yang dikaji berdasarkan penelitian terdahulu yang dianggap relevan terkait dengan variabel yang diteliti, tentang analisis penggunaan media papan planel untuk meningkatkan minat belajar anak pada materi rantai makanan di Sekolah Dasar. Berdasarkan analisis yang dilakukan terdapat pengaruh terhadap meningkatnya minat belajar anak pada materi rantai makanan dengan menggunakan media papan planel.
\end{abstract}

Kata Kunci : Media Papan Planel, Minat Belajar, Rantai Makanan

\begin{abstract}
This study was conducted with the aim of knowing the effect of using the planel board media to increase interest in learning about food chain materials in elementary schools. The type of research used is library research. The data collection technique in this research is to collect scientific journals that are considered relevant to the research variables, namely the media of planel boards, learning interests and food chain materials. Then it is presented and analyzed and processed so that it is concise and systematic. In library research, there are two sources of data, namely primary data sources and secondary data sources. The data analysis technique used is the researcher uses three methods of qualitative data analysis, namely data reduction, data presentation, and data conclusion/verification. The results of the research that were reviewed were based on previous research that was considered relevant related to the variables studied, regarding the analysis of the use of planel board media to increase children's learning interest in food chain materials in elementary schools. food using a planel board media.
\end{abstract}

Keywords : Planel Board Media, Learning Interest, Food Chain Rantai

\section{A. Pendahuluan}

Pendidikan adalah usaha sadar manusia untuk menumbuhkan dan mengembangkan potensi-potensi pembawaan baik jasmani maupun rohani sesuai dengan nilai-nilai yang ada dalam masyarakat dan kebudayaan, Sehingga kemajuan suatu bangsa tidak terlepas dari faktor pendidikan, karena pendidikan mempunyai peranan penting dalam usaha meningkatkan sumber daya manusia (SDM) yang merupakan unsur penting dalam pembangunan suatu bangsa. Usaha dalam rangka mencapai tujuan pendidikan, maka penyelenggaraan pendidikan perlu disesuaikan dengan pembangunan dan 
perubahan masyarakat. Sekolah sebagai lembaga pendidikan formal satu-satunya yang diselenggarakan pemerintah memegang peranan penting dalam mewujudkan tujuan pendidikan nasional.

Pendidikan yang berkualitas adalah suatu kegiatan belajar mengajar yang didukung oleh proses pembelajaran yang efektif, anak cepat memahami apa yang diajarkan, pembaharuan kurikulum, peningkatan kualitas guru, pengadaan sarana dan prasarana yang lengkap pada masing-masing sekolah. Dalam perkembangannya sampai saat ini, tampak jelas bahwa masalah yang serius dalam peningkatan kualitas pendidikan di Indonesia adalah rendahnya kualitas pendidikan pada jenjang Sekolah Dasar. Disisi lain faktor yang mempengaruhi kualitas pendidikan adalah rendahnya minat belajar anak terhadap mata pelajaran.

Menurut Rusman, (2017:76), belajar merupakan suatu aktivitas yang dapat dilakukan secara psikologis maupun fisiologis. Aktifitas yang bersifat psikologis yaitu, aktivitas yang merupakan proses mental, misalnya aktivitas berpikir, memahami, menyimpulkan, menyimak, menelaah, membandingkan, membedakan, mengungkapkan, dan menganalisis. Adapun aktivitas yang bersifat fisiologis yaitu aktivitas yang merupakan proses penerapan atau praktik, misalnya melakukan eksperimen atau percobaan, latihan, kegiatan praktik, dan membuat karya (produk). Menurut Susanto, (2016:4), belajar adalah suatu aktivitas yang dilakukan seseorang dengan sengaja dalam keadaan sadar untuk memperoleh suatu konsep, pemahaman, atau pengetahuan baru sehingga memungkinkan terjadinya perubahan perilaku pada seseorang yang relatif tetap baik dalam berpikir, merasa, maupun dalam bertindak. Dari pendapat tentang belajar di atas dapat disimpulkan bahwa belajar adalah usaha sadar seseorang dalam aktivitas psikologis maupun fisiologisnya untuk memperoleh konsep, pemahaman atau pengetahuan serta perubahan sikap yang lebih baik.

Proses pembelajaran yang kurang kondusif menyebabkan rendahnya minat belajar anak pada mata pelajaran IPA. Meskipun mata pelajaran IPA merupakan mata pelajaran wajib bagi setiap sekolah, kurangnya minat belajar anak disebabkan kurang afektifnya guru dalam menyampaikan materi. Maka dari itu dibutuhkan suatu media untuk meningkatkan minat belajar anak pada materi rantai makanan.

Media papan planel merupakan kegiatan pembelajaran yang sangat penting sebagai langkah dalam membentuk kemampuan pengembangan kognitif anak khususnya mengenal bentuk rantai makanan. Mengenal bentuk rantai makanan untuk anak Sekolah Dasar adalah kemampuan anak mengenal, menunjuk, menyebutkan bentuk-bentuk rantai makanan dalam kehidupan.

Berdasarkan hasil observasi yang dilakukan penulis di MI Al Ma'Arif Kota Ternate dapat diamati bahwa adanya fenomena antara lain : Pertama, guru mata pelajaran Ilmu Pengetahukan Alam dalam melaksanakan proses belajar mengajar kurang mengunakan alat peraga atau media pengajaran Kedua, Penjelasan guru yang bersifat lisan menyebabkan anak kurang mengerti akan materi pelajaran dan sering kali mengakibatkan kebosanan pada anak, sehingga minat belajar anak pada mata pelajaran IPA nya masih rendah. Ketiga, kurangnya kreativitas guru untuk membuat media pembelajaran dalam proses penyampaian materi pelajaran IPA di dalam kelas. 
Berdasarkan latar belakang masalah di atas maka minat belajar anak perlu ditingkatkan terutama pada materi rantai makanan. Untuk meningkatkan minat belajar anak, maka salah satu media pembelajaran yang dapat digunakan yaitu media papan planel. Atas dasar inilah penulis tertarik untuk melakukan penelitian dengan judul “Analisis Penggunaan Media Papan Planel Untuk Meningkatkan Minat Belajar Pada Materi Rantai Makanan Di Sekolah Dasar"

\section{B. Metode Penelitian}

Penelitian ini menggunakan pendekatan kualitatif, serta jenis penelitian yang digunakan adalah studi pustaka (library research), dengan menggunakan sumber data berupa buku-buku referensi dan artikel-artikel jurnal ilmiah. Pada penelitian ini rangkaian kegiatannya berkenaaan dengan pengumpulan data pustaka, membaca dan mencatat, lalu mengolah informasi yang sesuai dan diperlukan untuk menjawab rumusan masalah yang akan dipecahkan. Hal ini diperkuat dengan pendapat Zed tentang Penelitian studi pustaka. Menurut Zed, (2014: 3), Studi pustaka (library research) merupakan serangkaian kegiatan yang berkenaan dengan metode pengumpulan data pustaka, membaca dan mencatat serta mengelolah bahan penelitian. Sedangkan menurut Natsir (2013) Studi kepustakaan adalah teknik pengumpulan data dengan mengadakan studi penelaahan terhadap buku-buku, literatur-literatur, catatan-catatan, dan laporan-laporan yang ada hubungannya dengan masalah yang dipecahkan (Natsir, 2013: 93).

\section{Sumber Data}

\section{Data Primer}

Data primer, yaitu data yang diperoleh dari referensi yang lebih banyak membahas tentang tentang fokus-fokus penelitian. Data peneliti peroleh dari Google cendekiawan.

\section{Data Sekunder}

Data sekunder, yaitu data yang diperoleh penulis untuk menanggapi dan mendukung data primer. Data peneliti peroleh dari Google cendekiawan.

\section{Teknik Pengumpulan Data}

\section{Observasi}

Observasi yaitu teknik pengumpulan data dengan cara melakukan pengamatan langsung terhadap objek yang diteliti. Dalam observasi ini peneliti melakukan observasi kepustakaan dari jurnal-jurnal yang relevan dengan variabel penelitian.

\section{Dokumentasi}

Dokumentasi yaitu teknik non interaksi yang dilakukan oleh peneliti agar data yang diperoleh semakin kuat. Dalam dokumentasi ini peneliti melakukan pengumpulan data dari jurnal-jurnal yang relevan dengan variabel penelitian. 


\section{E. Analisis Data}

Analisis data merupakan langkah terpenting dalam suatu penelitian. Data yang diperoleh kemudian dianalisis sehingga dapat ditarik kesimpulan oleh peneliti. Dalam penelitian ini peneliti menggunakan analisis data Miles \& Huberman, (2009: 16-20), yaitu sebagai berikut:

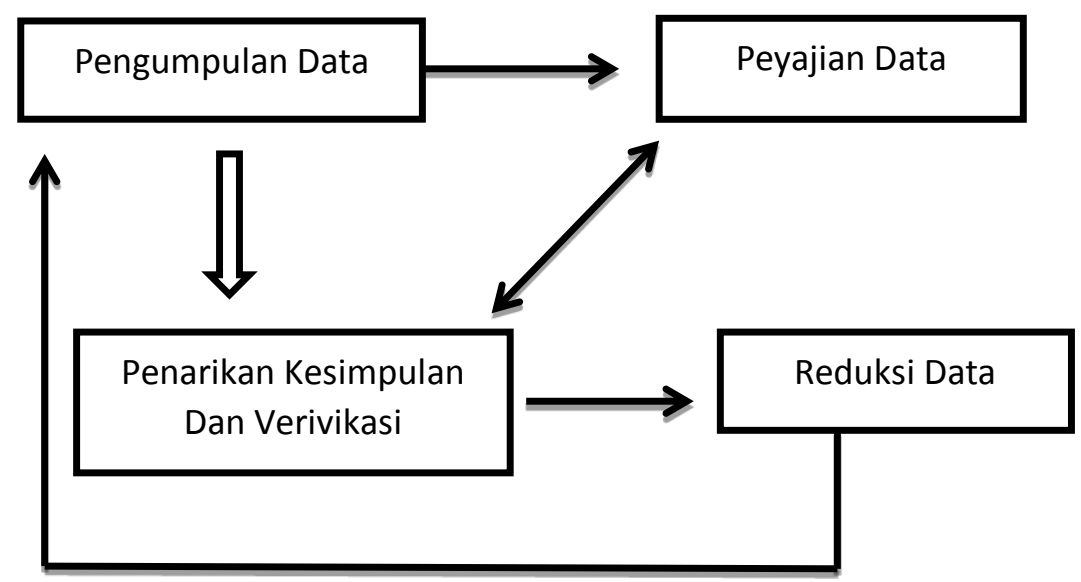

\section{Reduksi Data}

Reduksi data diartikan sebagai proses pemilihan, pemusatan perhatian pada penyederhanaan, pengabstrakan, dan trasnformasi data "kasar" yang muncul dari catatan-catatan tertulis di lapangan. Reduksi data, berlangsung secara terus-menerus selama proyek yang berorientasi kualitatif berlangsung. Sebenarnya bahkan sebelum data benar-benar terkumpul. Antisipasi akan reduksi data sudah tampak waktu penelitinya memutuskan (acapkali tanpa disadari sepenuhnya) kerangka konseptual wilayah penelitian, permasalahan penelitian, dan pendekatan pengumpulan data, yang mana yang dipilihnya. Selama pengumpulan data berlangsung terjadi tahapan reduksi selanjutnya (membuat ringkasan, mengkode, menelusur tema, membuat gugusangugusan, membuat partisi, menulis memo). Reduksi data/proses-transformasi ini berlanjut terus sesudah penelitian lapangan, sampai laporan akhir lengkap tersusun.

Reduksi data merupakan suatu bentuk analisis yang menajamkan, menggolongkan, mengarahkan, membuang yang tidak perlu, dan mengorganisasi data dengan cara sedemikian rupa sehingga kesimpulan finalnya dapat ditarik dan diverifikasi.

\section{Penyajian Data}

Penyajian data adalah penyajian sekumpulan informasi tersusun yang memberikan kemungkinan adanya penarikan kesimpulan dan pengambilan tindakan. Penyajian data dilakukan secara sistematis semuanya dirancang guna menggabungkan informasi yang disusun dalam suatu bentuk yang padu dan mudah diraih, dengan demikian seorang peganalisis dapat melihat apa yang sedang terjadi, dan menentukan apakah menarik kesimpulan yang benar ataukah terus melangkan melakukan analisis.

\section{Penarikan kesimpulan dan Verifikasi}

Penarikan kesimpulan merupakan kegiatan konfigurasi yang utuh. Merupakan kegiatan analisis ke tiga yang terpenting. Setelah kesimpulan-kesimpulan ditarik kemudian kesimpulan-kesimpulan tersebut diverifikasi selama penelitian berlangsung. Verifikasi ini berupa peninjauan ulang catatan-catatan lapangan dimana 
data-data harus diuji kebenarannya, kekokohannya dan kecocokannya. Jika tidak demikian kesimpulan-kesimpulan yang ditarik tidak jelas kebenarannya dan kegunaannya.

\section{F. Analisis Penggunaan Media Papan Planel untuk Meningkatkan Minat Belajar pada Materi Rantai Makanan di Sekolah Dasar}

Penelitian merupakan penelitian dengan menggunakan metode study pustaka (library research), dimana penulis berusaha menganalisis hasil penelitian yang relevan dengan judul pada penelitian ini. Penulis berusaha menganalisis penggunaan media papan planel untuk meningkatkan minat belajar pada materi rantai makanan di Sekolah Dasar dengan mengacu pada jurnal yang di anggap relevan seperti penelitian yang dilakakukan oleh penulis. Maka hasil dari penelitian ini untuk meningkatkan minat belajar pada materi rantai makanan dalam pembelajaran IPA dengan memanfaatkan media papan planel, khususnya pada anak Sekolah Dasar kelas rendah.

Pertama, Penelitian yang dilakukan oleh Agustin pada tahun 2016. Bertujuan untuk mengetahui pengaruh pendidikan kesehatan dengan media papan planel terhadap tindakan mencuci tangan dengan air bersih dan sabun pada anak. Latar belakang dari tujuan tersebut dikarenakan banyak permasalahan kesehatan yang sangat menentukan kualitas anak usia sekolah di masa depan. Secara epidemiologis, penyebaran penyakit berbasis lingkungan dikalangan anak sekolah di Indonesia tergolong sangat tinggi. Peneliti juga merumuskan hipotesis dalam penelitian tersebut adalah Ada perbedaan yang signifikan setelah diberikan pendidikan kesehatan melalui media permainan papan planel terhadap tindakan mencuci tangan dengan air bersih dan sabun pada anak Sekolah Dasar di SD Muhammadiyah 26 Surabaya.

Hasil uji statistik Wilcoxon Sign Rank Test didapatkan hasil nilai $\rho=0,000$. Nilai tersebut kurang dari $\alpha(0,05)$. Sehingga dapat disimpulkan $\mathrm{H}_{0}$ ditolak yang berarti bahwa terdapat perbedaan yang signifikan setelah diberikan pendidikan kesehatan dengan media papan planel terhadap tindakan mencuci tangan dengan air bersih dan sabun pada anak Sekolah Dasar di SD Muhammadiyah 26 Surabaya. Berdasarkan hal tersebut penulis menyimpulkan adanya perbedaan peningkatan perilaku anak setelah menggunakan media papan planel yang diterapkan oleh guru. Hal ini dikuatkan dengan pendapat Ratna Agustik selaku peneliti dalam penelitian tersebut berpendapat bahwa papan planel merupakan media pembelajaran yang dapat menarik perhatian sehingga menimbulkan dampak positif terhadap perubahan tindakan anak dalam mencuci tangan dengan air bersih dan sabun.

Kelebihan dalam penelitian tersebut adalah media papan planel dapat menarik perhatian anak sehingga anak dapat mengerti serta menerapkan cuci tangan dengan air bersih dan sabun. Hal ini sejalan dengan pendapat Daryanto, (2012: 22), fungsi media papan planel adalah untuk jenis pelajaran apa saja, dapat menerangkan perbandingan atau persamaan secara sistematik, dan dapat menarik minat anak untuk belajar aktif.

Selain itu jika mengacu pada faktor yang mempengaruhi minat belajar anak, penggunaan papan planel merupakan faktor yang berpengaruh terhadap minat belajar anak. Hal ini disebabkan guru berhasil menerapkan suatu media pembelajaran yang dapat meningkatkan minat belajar anak, salah satu media yang diterapkan oleh guru dalam penelitian tersebut adalah penggunaan media papan planel. Faktor tersebut juga sejalan 
dengan pendapat Prahmadita, (2014: 12) menyebutkan bahwa guru yang berhasil membina kesediaan belajar anak didiknya. Maksud kesediaan belajar disini adalah penggunaan media pembelajaran.

Sedangkan kekurangan dalam penelitian tersebut adalah anak cenderung akan mengerti terhadap pengertian materinya saja, karena mencuci tangan merupakan sebuah tindakan sedangkan papan planel kebanyakan hanya menerangkan terhadap pengertian sebuah materi.

Kedua, Penelitian yang dilakukan oleh Fitriana dan Handayani pada tahun 2017 dengan judul Pengembangan media papan planel tema pekerjaan kelas III Sekolah Dasar. Penelitian ini merupakan penelitian pengembangan, dimana peneliti berusaha mengetahui pengembangan dan kelayakan media papan planel melalui pendekatan tematik pada kurikulum KTSP. Pengembangan tersebut dilakukan dengan cara memodifikasi papan planel yang sudah ada dengan gambar bercerita dan dilengkapi icon-icon dua dimensi yang dikemas peti tema pekerjaan dengan cakupan materi lebih luas. Pada penelitian tersebut untuk megetahui kelayakan media papan planel maka dilakukan uji validasi ahli media dan ahli materi, hasil angket respon anak, hasil evaluasi anak dan hasil angket keberterimaan juru praktisi.

Hasil uji validasi ahli media dari tahap pertama sampai tahap ketiga mengalami kenaikan presentase yaitu dari 58\% dalam kriteria cukup layak, 74\% dalam kriteria layak, dan $98 \%$ dalam kriteria sangat layak. Hal tersebut menunjukan bahwa media papan planel layak untuk digunakan sebagai media pembelajaran karena dinilai konkret dengan kondisi lingkungan sekolahan (Fitriana \& Endah, 2017: 111).

Berdasrkan presentase terhadap setiap aspek penilian penulis menyimpulkan bahwa media papan planel sangat layak digunakan sebagai media pembelajaran. Hal ini sesuai dengan indikator minat belajar menurut Slameto(2010: 180) yang menyatakan bahwa ada beberapa indikator terhadap minat belajar antara lain adalah perasaan senang, keterlibatan anak, ketertarikan serta perhatian anak.

Ketiga, Penelitian tersebut dilakukan pada tahun 2018 oleh Rahayu dan Paksi dari Universitas Negeri Surabaya. Tujuan dari penelitian tersebut adalah untuk mengetahui pengembangan media papan planel berputar dan kelayakan media papan planel berputar yang dikembangkan. Dengan metode penelitan yang mereka gunakan adalah metode pengembangan serta menggunakan model 4-D yang terdiri dari tiga tahap antara lain pendefinisian, perancangan, dan pengembangan.

Tahap pertama pendefisinan terdapat beberapa fase, antara lain : fase Pertama adalah ujung depan, pada fase ini ditemukan masalah pada anak SDN Ngampel II dan SDN ngampel III dimana anak mengalami kesalahan pemahaman materi dampak globalisasi dengan membedakan dampak positif dan dampak negatif globalisasi. Fase kedua adalah analisis tugas, fase tersebut menjelaskan data karakteristik anak yang berdasarkan observasi. Fase ketiga analisis tugas, agar anak dapat mencapai kompetensi dasar, maka dilakukan analisis tugas yang menjadi acuan dalam merancang tugas untuk diselesaikan anak. Fase keempat perumusan tujuan pembelajaran, penyusunan tujuan pembelajaran didasarkan pada kompetensi dasar dan indikator yang tercantum dalam kurikulum KTSP.

Tahap kedua perancangan, dengan fase sebagai berikut : fase pertama penyusunan tes acuan patokan, disesuaikan dengan patokan pembuatan media yaitu materi, SK, KD, 
dan indikator yang akan digunakan. Fase kedua pemilihan media, disesuaikan dengan hasil analisis ujung depan yang berkaitan dengan permasalahan yang ditemukan di lapangan dan kebutuhan yang muncul akibat adanya permasalahan tersebut. Fase ketiga pemilihan format, dimaksudkan untuk mendesain isi media pembelajaran yang disesuaikan dengan materi pembelajaran, SK, KD, dan indikator yang digunakan. Fase keempat rancangan awal, hasil perancangan awal pada fase ini meliputi rancangan media yang digunakan untuk memperoleh data yang dibutuhkan dalam proses pengembangan.

Ketiga tahap pengembangan (develop) dengan fase: fase pertama validasi ahli, media papan planel berputar yang telah dirancang dan dibuat akan dilakukan validasi media. Sebelum melakukan validasi pada media terlebih dahulu dilakukan validasi pada materi oleh validator materi. Fase kedua uji coba produk, dilakukan setelah media selesai divalidasi dan direvisi.

Berdasarkan tiga tahapan yang telah dilakukan oleh peneliti tersebut, dihasilkan suatu penjelasan terhadap media papan planel. Menurut beliau Media papan planel berputar merupakan media visual dengan media papan planel sebagai komponen utama media. hal ini sejalan pendapat Sanaky, (2011: 61), papan planel termasuk salah satu media pembelajaran visual dua dimensi, yang dibuat dari kain planel yang ditempelkan pada sebuah papan atau tripleks, kemudian membuat guntingan-guntingan kain planel atau kertas rempelas yang diletakkan pada bagian belakang gambar-gambar yang berhubungan dengan bahan-bahan pelajaran.

Peneliti pada penelitian ini juga menyebutkan tujuan dari media papan planel adalah untuk membantu guru dalam menyampaikan materi pada anak dan meningkatkan pemahaman anak terhadap materi dampak globalisasi yang diajarkan guru. Disisi lain media ini dapat meningkatkan motivasi dan dorongan dari dalam diri anak. Hal ini juga sejalan dengan pendapat Sadiman dkk, (2010: 48), papan planel adalah media grafis yang efektif sekali untuk menyajikan pesan-pesan tertentu kepada sasaran tertentu pula.

Kelebihan dari penelitian ini adalah pengembangan media papan planel berputar adalah memberikan varian media pembelajaran. Selain itu media papan planel berputar memiliki keunggulan yaitu mempermudah guru untuk menjelaskan suatu materi, hal ini dikarenakan media papan planel berputar terdiri dari sepuluh papan yang dapat diputar bergantian. Selain itu keunggulan lain media papan planel berputar memiliki sisi yang dapat dimainkan dan dapat mempelajari materinya. Sejalan dengan Kustandi dan sutjipto, (2013: 47), menyatakan bahwa kelebihan papan planel adalah Dapat memusarkan perhatian anak terhadap materi pelajaran.

Kelemahan pada media papan planel berputar yang dikembangkan oleh Puji Rahayu dan Hendrik Paksi adalah proses pembuatan media papan planel berputar lebih rumit dibandingkan media papan planel biasa. Hal tersebut tentunya menjadi permasalahan pada guru yang memiliki keterbatasan alat dan bahan.

Keempat, Penelitian Yang dilakukan oleh Yulistia, penelitian ini dilakuakan pada tahun 2019 dengan tujuan Tujuan penelitian ini adalah untuk mengetahui penggunaan media papan planel dalam mengembangkan kemampuan berhitung permulaan anak kelompok A di Taman Kanak-kanak Alam Baradatu Way Kanan.

Hasil penelitian menunjukkan bahwa langkah-langkah penggunaan media papan planel dalam mengembangkan kemampuan berhitung permulaan pada anak kelompok A 
di Taman Kanak-kanak Alam Baradatu Way Kanan yaitu : (1) Memilih tema kegiatan yang akan dilakukan, (2) Memilih dan menyiapkan item-item papan planel yang sesuai dengan tema, (3) Mengatur posisi media papan planel agar terlihat jelas oleh anak, (4) Menerangkan kegiatan yang akan dilakukan dan melakukan kegiatan tanya jawab. Dari keempat langkah-langkah tersebut mampu mengembangkan kemampuan berhitung permulaan anak kelompok A.

Peneliti pada penggunaan media papan planel. langkah-langkah tersebut menunjukan kemudahan penggunaan media papan planel. Kemudahan ini juga sebanding dengan kelebihan penggunaan papan planel menurut Kustandi dan sutjipto, (2013: 47), antara lain: Guru dapat membuat media papan planel sendiri, media ini dapat dipersiapkan terlebih dahulu dengan teliti dan cermat, dapat memusarkan perhatian anak terhadap materi pelajaran dan menghemat waktu pembelajaran, karena segala sesuatu sudah dipersiapkan dan anak dapat melihat sendiri secara langsung

Kelima, Penelitian yang dilakukan oleh Rohmatun pada tahun 2020 merupakan penelitian tindakan kelas dimana tujuan dari penelitian ini adalah untuk mengetahui apakah penggunaan model pembelajaran Scramble dengan media papan planel ini dapat meningkatkan hasil belajar dan mengetahui apakah media tersebut dapat memenuhi target KKM 85\% pada mata pelajaran IPA Materi Daur Hidup Hewan pada anak kelas IV di MI Ma'arif Sraten Tahun Pelajaran.

Hasil penelitian menujukan bahwa model pembelajaran Scramble dengan media papan planel dapat meningkatkan hasil belajar mata pelajaran IPA materi Daur Hidup Hewan pada anak kelas IV MI Ma'arif Sraten tahun 2019/2020. Hal ini dibuktikan dengan data yang diperoleh per-siklusnya, hasil pra siklus hanya ada 5 anak $(31,25 \%)$ yang tuntas KKM, sedangkan 11 anak $(68,75)$ belum tuntas KKM. Selanjutnya hasil dari Siklus 1 sebanyak 9 anak (56,25\%) yang tuntas KKM, sedangkan 7 anak $(43,75 \%)$ belum tuntas KKM dengan ratarata 69,69. Diperoleh peningkatan hasil belajar dari pra siklus ke siklus I yaitu $25 \%$. Pada siklus II sebanyak 14 anak $(87,5 \%) \geq 85 \%$ yang tuntas KKM, sedangkan 2 anak $(12,5 \%)$ belum tuntas KKM dengan nilai rata-rata 81,25. Peningkatan hasil belajar dari siklus I ke siklus II yaitu 31.25\%.

Pada tahap siklus I, peneliti menerapkan model pembelajaran Scrambel dengan media papan planel. setelah dilakukan penelitian, hasil belajar anak mengalami peningkatan yang signifikan. Hal ini dibuktikan dengan nilai anak yang tuntas pada mata pelajaran IPA adalah sebanyak 56,25 \% sedangkan yang tidak tuntas adalah sebanyak 43,75 \%. Berdasarkan data tersebut peneliti menyimpulkan bahwa dengan penggunaan media papan planel dapat meningkatkan hasil belajar anak. Hal tersebut sejalan dengan Daryanto, (2012: 22), yang menyebutkan bahwa fungsi media papan planel adalah untuk jenis pelajaran apa saja, dapat menerangkan perbandingan atau persamaan secara sistematik, dan dapat menarik minat anak untuk belajar aktif. Dari pendapat tersebut dapat disimpulkan bahwa media papan planel dapat menarik anak untuk belajar secara aktif sehingga dapat berpengaruh pada peningkatan hasil belajar anak.

Pada siklus II, didapat data yang sangat signifikan terhadap hasil belajar anak, yaitu sebanyak 14 anak berhasil memenuhi KKM dengan prosentase sebanyak 87,5 \% sedangkan anak yang belum mencapai KKM adalah 2 anak dengan prosentase 12,5\%. Berdasarkan hasil belajar anak yang telah dicapai pada siklus II, dapat disimpulkan bahwa 
penggunaan media papan planel sangat efektif digunakan oleh guru sebagai media pembelajaran karena dapat meningkatkan hasil belajar anak dengan maksimal. Hal ini pun sesuai dengan fungsi media papan planel menurut Sanaky, (2011: 62), menyebutkan bahwa: media papan planel Membantu pengajar untuk menerangkan bahan pelajaran, Mempermudah pemahaman pembelajar tentang bahan pelajaran dan Agar bahan pelajaran lebih menarik. Peneliti pada penelitian tersebut juga mengungkapkan bahwa Pembelajaran Scramble dengan Media Papan Planel mempunyai pengaruh positif terhadap pembelajaran, yaitu dapat meningkatkan kreatifitas anak dalam mengikuti pembelajaran, anak lebih bersemangat dalam pembelajaran, sehingga tujuan pembelajaran dapat tercapai.

\section{G. Simpulan}

Berdasarkan analisis serta pembahasan yang telah dipaparkan pada bagian sebelumnya terhadap pemanfaatan media papan planel sebagai upaya meningkatkan minat belajar anak pada materi rantai makanan, maka peneliti menarik kesimpulan bahwa untuk membangun minat belajar anak dalam pembelajaran khusunya pada materi rantai makanan sangat bergantung pada guru, dimana sebagai seorang guru dituntut harus inovatif dan kreatif dalam melakukan pembelajaran, dengan menghadirkan atau memanfaatkan media yang tepat dalam proses pembelajaran hal ini didasarkan pada penelitian terdahulu, yang dimana dengan adanya sebuah media akan dapat membagun minat belajar anak itu sendiri sebab media lebih banyak bertindak sebagai bahan ajar.

Dengan penggunaan media papan planel sangat menarik perhatian anak dan sangat mudah dilakukan dalam pembelajaran rantai makanan, sebab didalamnya terdapat unsur permainan yang sangat disukai anak-anak. Selain itu, papan planel juga melatih kreatifitas anak dalam mengenal gambar-gambar serta tulisan dengan mudah sehingga dapat mengingat urutan rantai makanan dengan mudah.

\section{DAFTAR PUSTAKA}

Agustin, R. 2016. Pengaruh Pendidikan Kesehatan Dengan Media Papan Planel Terhadap Tindakan Mencuci Tangan Dengan Air Bersih Dan Sabun Pada Anak Sekolah Dasar di SD Muhammadiyah 26 Surabaya. Surabaya: Lembaga Penelitian dan Pengabdian Masyarakat Niversitas Muhammadiyah Surabaya.

Daryanto. 2012. Media Pembelajaran. Bandung: PT. Sarana Tutorial Nurani Sejahtera.

Fitria, W. \& Handayani, E. D. (2017). Pengembangan Papan Planel Tema Pekerjaan Kelas III Sekolah Dasar. Jurnal Pendidikan: Vol (11), No (2), Hal (106).

Kustandi, C. dan Sutjipto, B. 2013. Media Pendidikan ; Manual dan Digital. Bogor: Ghalia Indonesia.

Miles, M. dan Huberman M. 2017. Analisis Data Kualitatif. Jakarta: UI Press.

Natsir, M. 2013. Metode Penelitian. Bogor: Ghalia Indonesia. 
Prahmadita, A. D. 2015. Faktor-Faktor yang Mempengaruhi Minat Anak untuk Mengikuti Ekstrakulikuler Drumbanddi SMP Negeri 1 Sleman. Fakultas Bahasa dan Seni. Yokyakarta: Universitas Negeri Yokyakarta.

Rahayu, P. \& Paksi, H.P. 2018. Pengembangan Media Papan Planel Berputar untuk Membantu Guru Memahamkan Materi Dampak Globalisasi Terhadap Anak SD. JPGSD. Vol (6), No (4), Hal (546).

Rohmatun, A. 2020. Upaya Meningkatkan Hasil Belajar IPA Materi Daur Hidup Hewan Melalui Model Pembelajaran Scramble dengan Media Papan Planel Pada Anak Kelas IV di Mi Ma'arif Sraten Tahun Pelajaran 2019/2020. Salatiga: Institut Agama Islam Negeri (IAIN) Fakultas Tarbiyah dan Ilmu Kependidikan (FTIK).

Rusman. 2017 Belajar \& Pembelajaran Berorientasi Standar Proses Pendidikan. Bandung: Kencana.

Sadiman, A. S. Dkk, 2010, Media Pendidikan: Pengertian, Pengembangan dan Pemanfaatannya, Depok: Rajawali.

Sanaky, H. A. H. 2011. Media Pembelajaran. Yogyakarta: Kaukaba.

Slameto. 2015. Belajar Dan Faktor-Faktor Yang Mempengaruhi. Jakarta: Rineka Cipta.

Susanto, A. 2016. Teori Belajar \& Pembelajaran di Sekolah Dasar. Jakarta: Kencana.

Yulistia, I. 2019. Penggunaan Media Papan Planel Dalam Mengembangkan Kemampuan Berhitung Permulaan pada Anak Kelompok A di Taman Kanak-Kanak Alam Baradatu Waykanan. Lampung: Fakultas Tarbiyah dan Kependidikan Universitas Islam Negeri Raden Intan Lampung

Zed, M. 2014. Metode Penelitian Kepustakaan. Jakarta: Yayasan Obor Indonesia. 